\title{
Klokt forslag om aborthenvisning
}

Kvinner som tar abort, må vite hva de gjør. Mange kvinner er ambivalente og trenger informasjon og rådgivning fra legen for å ta det riktige valget. Lettvinte og ugjennomtenkte valg må unngås, og legenes samvittighet må respekteres.

Etter lang erfaring er jeg kommet til den erkjennelse at en kvinne som tar abort, må være helt sikker på at hun vil det. Hun må vite inni seg at det er det eneste rette for henne i den situasjonen hun er kommet opp i. Det er et alvorlig valg som for mange krever mye energi og som kvinnen må legge hele sin sjel $i$, hele sin indre personlighet. Hun må vite hva hun gjør, og da gjør hun det rette!

Min erfaring er at mange kvinner blir forferdet når de oppdager at de er blitt gravide. Flere får panikk, vil flykte fra problemet og ta abort så snart som mulig. De evner ikke, eller vil ikke, bearbeide tilstanden på en forsvarlig måte. De lukker øynene og forlanger svangerskapet avsluttet så fort som mulig. De gjør galt og handler ugjennomtenkt.

Mange kvinner er ambivalente til om de skal ta abort, og de trenger hjelp til å ta beslutningen. Det er vår oppgave som leger å hjelpe disse kvinnene til å se alvoret i situasjonen slik at de kan gjøre et reflektert valg. De må være klar over at provosert abort ikke er en avsluttet prosess, men en del av deres livshistorie. Legen må forklare inngrepets art og mulige bivirkninger. Kvinnen må ha klart for seg at kortsiktige, umiddelbare og trivielle problemer som jobb, utdanning, husvære eller andre sosioøkono- miske problemer har liten betydning i denne sammenheng, selv om de for henne kan fortone seg store i øyeblikket. Jeg mener provosert abort må ses i et livslangt perspektiv.

Kvinnen må være på vakt slik at hun ikke blir presset til å ta abort av andre, for eksempel mann eller foreldre. Legen skal ikke gi henne konkrete råd, men hjelpe henne

\section{«Manglende reserva- sjonsrett vitner om liten respekt for legeyrket»}

til å ta en for henne riktig beslutning. For å bearbeide problemet trenger hun ofte tid, og da vil det være nyttig å avtale ny time om en uke, såfremt det er innenfor 12-ukersregelen. Noen leger har en lettvint holdning til abort, skriver raske henvisninger og gir lite informasjon, andre er mer restriktive og tar seg tid til å bearbeide problemet sammen med kvinnen.

Manglende reservasjonsrett vil medføre favorisering av lettvinte løsninger og innskrenking av handlefrihet og legens rolle.
Det er verken samfunnet eller den enkelte kvinne tjent med. Vi gjør da de abortsøkende kvinner en bjørnetjeneste. Manglende reservasjonsrett vitner om liten respekt for legeyrket og intoleranse overfor de leger som av samvittighetsgrunner ikke vil være med på provosert abort. Regjeringens nye forslag om at fastlegene ikke lenger skal henvise til abort, men allikevel kunne gi råd og informasjon ved behov, er klokt og burde være akseptabelt også for dagens reservasjonsleger.

\section{Alf Kristoffersen \\ alf.kristoffersen@skanland.nhn.no}

Alf Kristoffersen (f. 1945) er spesialist i allmennmedisin og i fødselshjelp og kvinnesykdommer. Han arbeider ved Skånland legesenter. Forfatter har fylt ut ICMJE-skjemaet og oppgir ingen interessekonflikter.

Mottatt 28.4. 2014, første revisjon innsendt 8.5. 2014, godkjent 12.5. 2014. Redaktør: Hanne Støre Valeur.

Publisert først på nett. 